\title{
Inclusive Leadership of School Management from the View of Families: Construction and Validation of LEI-Q
}

\author{
María del Carmen López-López (D), María José León Guerrero $\mathbb{D}$ and Emilio Crisol-Moya *(D)
}

Citation: López-López, M.d.C.; León Guerrero, M.J.; Crisol-Moya, E. Inclusive Leadership of School Management from the View of Families: Construction and Validation of LEI-Q. Educ. Sci. 2021, 11, 511. https://doi.org/10.3390/ educsci11090511

Academic Editor: John De Nobile

Received: 21 July 2021

Accepted: 1 September 2021

Published: 6 September 2021

Publisher's Note: MDPI stays neutral with regard to jurisdictional claims in published maps and institutional affiliations.

Copyright: (c) 2021 by the authors. Licensee MDPI, Basel, Switzerland. This article is an open access article distributed under the terms and conditions of the Creative Commons Attribution (CC BY) license (https:// creativecommons.org/licenses/by/ $4.0 /)$.
Department of Didactics and School Organization, University of Granada, 18071 Granada, Spain; mclopez@ugr.es (M.d.C.L.-L.); mleon@ugr.es (M.J.L.G.)

* Correspondence: ecrisol@ugr.es; Tel.: +34-958-242-779

\begin{abstract}
The purpose of this study was to validate a questionnaire aimed at assessing, from the point of view of families, the degree to which school administrations foster inclusion in compulsory education. In order to determine the psychometric properties of the "Cuestionario liderando la educación inclusiva en centros de educación obligatoria-Familias" [Leading inclusive education in compulsoryeducation schools Questionnaire] (LEI-Q-Families), we carried out descriptive, exploratory, and confirmatory factor analysis. For the sample used in this study, 150 families participated. The results confirmed that it is a valid and reliable scale with a two-factor structure. One of these factors included the initiatives carried out by the school management teams to enhance the openness of each school to the community and the surrounding area. The second factor encompassed actions aimed at promoting participation in the school and turning it into an inclusive space. LEI-Q-Families proved to be an instrument of great theoretical and practical worth that has made it possible to expand our currently slender knowledge on the perceptions families have of the work done by school managers to encourage inclusion in their institutions. It facilitates family participation in processes of improvement and provides a useful self-assessment tool for school administrations that wish to improve their schools and turn them into inclusive environments.
\end{abstract}

Keywords: school leaders; inclusion; families; leadership evaluation; school improvement

\section{Introduction}

Traditionally, the family-school relationship has not only been limited but has also been marked by disagreement and mutual lack of trust. The pejorative assessments that are given of each other frequently reflect stereotypical views that hinder understanding and collaboration between the two parties. This tendency has led teachers and school managers to denounce the lack of interest and commitment of families in the education of their children, while it causes families to disesteem the educational work of schools and to not consider their own participation in the pedagogic activities promoted by teachers as important [1,2]. This discord affects the development and performance of students, limits the possibilities of family participation in the school, and deteriorates the social image of the school, above all when it concerns families that are vulnerable, immigrants, or that do not fit the norm and who do not feel valued or represented in the educational institution [2-5].

Currently, diversity, social inequality, the growing complexity of contexts, and their transfer to educational processes all mean that it is essential to revert this situation of discord if we wish to guarantee inclusive and quality education for all $[6,7]$. Many studies have shown the positive effect of the involvement of students' families on their academic success and socio-emotional development [8-10]: "more and better ties between school and families, particularly those that are less familiar with school culture, make it possible to improve academic results" [8] (p. 40). Other studies underline the contribution of families and their community to the improvement of education, schools themselves, and, more specifically, of inclusivity programmes $[1,5,11,12]$. 
In order to progress toward inclusive, fair, and equitable education, we need to open schools up to family diversity and their environments, facilitating mutual exchange, active participation, a feeling of belonging, and the exercise of co-responsibility in children's education [2,13,14]. According to Liang and Cohrssen [4], it is not merely a question of enabling occasional participation linked to extracurricular activities, but of fostering a truly participatory culture based on mutual trust that strengthens the involvement of all families and their active participation in the decision making that affects student education, life in the school, its administration, and its institutional culture. To meet this challenge requires implementing new forms of running and leading schools, as shown by Okoko [5], Ryan [15], Wang [16], and Valdés [17].

Harris et al., [18], Grant and Ray [19], Liang and Cohrssen [4], and Shields [20] have emphasized the strategic role that school management plays in the development of more participatory school cultures when they practise distributed, democratic, transformative, and inclusive leadership. Exercising inclusive leadership means strengthening the ties between families and schools through a positive view of diversity; fostering the feeling of belonging through relationships based on mutual trust, collaboration, and joint responsibility; facilitating participation in decision making; urging teachers to reflect critically on their practice and to be actively involved in educational projects aimed at meeting the needs of all students and their families; and establishing shared commitments based on values of fairness, equality, and social justice $[13,15,16]$.

This commitment to inclusion should involve contemplation of the policies and privileged practices adopted by schools that restrict family participation and that often perpetuate the ideologies that, in a particular way, discriminate against families that are diverse or do not fit the norm and make them invisible [2]. Failing this, we run the risk of concealing the stigmatization that certain types of families suffer, most noticeably LGBTIQ families, as Liang and Cohrssen [4] argue. This will lead to the continuation of the dominant and exclusive cultural models that deny and limit the participation and representation of other types in schools. In terms of the practices that schools adopt, Boscardin and Shepherd [21] invite school managers to critically reflect upon assessment approaches and how these impact students with disabilities or with little cultural representation.

Unfortunately, the study carried out by Okoko [5] on the experiences of school managers with immigrant students and their families in Saskatchewan (Canada) has revealed two important issues. First, school leaders lack awareness about the connections between good management of family diversity and students' academic performance. Second, they have insufficient training for managing in an inclusive way the growing cultural diversity of immigrant students and their families. In Okoko's opinion, school leaders need to be more reflective and self-aware, to embrace cognitive dissonance as learning opportunities, and "to have knowledge, skills and dispositions for acknowledging and responding appropriately to difference and the associated stereotypes, cultural diversity with its infinite variations, relations between dominant and minority cultures, the role of parents, communities and inter-organizational partnerships" [5] (p. 195).

However, Celoria [22], León and López [23], and Liang and Cohrssen [4] have also shown the lack of training of school managers to be an obstacle to creating inclusive environments, and many authors have argued for the greater involvement of these professionals in these processes $[15,24,25]$. According to Liang and Cohrssen [4], what is needed is critical thinking on diversity, along with a transformation of practices and recognizing that the visibility of all families and their right to participation is a question of inclusion and social justice. Yet despite the relevance given to school leaders, very few studies have shown an interest in discovering the practices established by school managements to facilitate inclusion, deal with diversity, promote the participation of all families [26], open up more to the community, and improve its development [1].

Up until now, the few existing studies that analyse the work of school leaders in inclusion processes have done so from the perspective of the teachers or the school staff themselves $[24,25,27,28]$, but those that have done so from the families' perspective are 
practically non-existent [4]. This is just another example of the secondary role that families have received in the policies and practices of schools and of the scant interest shown until now by researchers in including their points of view and making their participation in the improvement of schools possible $[14,26]$. There is, therefore, a lack of empirical studies and evaluation instruments that collect the opinions of families on the actions undertaken by school administrations to encourage the inclusion of all students and to contribute to the development of more inclusive institutional cultures that are open to family diversity and to the community $[16,17,24]$. If we wish to advance toward a truly inclusive education in which families feel represented, valued, and welcome, we need studies that are themselves inclusive and that involve the participation of families in the analysis of the reality in education and the processes of improvement.

In this paper, we present an instrument aimed at assessing, from the perspective of the families, the degree to which actions undertaken by school managers to promote inclusion are implemented in compulsory education schools (students from the ages of 6 to 16). Although the instrument was constructed and validated in Spain, its application to other contexts is perfectly viable if, as Hambleton and Zenisky [29] state, it is duly adapted culturally, linguistically, idiomatically, and contextually. The initiative forms part of an investigation funded by the European Regional Development Fund (ERDF) and the Junta of Andalusia in Spain (Ref: B-SEJ-057-UGR18). This is an inclusive study that opens the doors to the participation of all families, giving them visibility and protagonism, helping them to feel appreciated, recognized, and valued. The study gathers their contributions and facilitates their participation in the improvement of inclusive school leadership, a key factor in the creation of schools of quality for everyone. Lastly, our study provides a useful self-assessment tool for school managers who wish to turn their schools into inclusive environments and helps to increase the limited knowledge we currently have on the perceptions the families hold about the work undertaken by school administrations to promote inclusion in their institutions.

\section{Materials and Methods}

\subsection{Statement of the Problem}

The purpose of this study is to design and validate the questionnaire, "Liderando la educación inclusiva en centros de educación obligatoria" ["Leading inclusive education in compulsory-education schools"] (LEI-Q) for families. Its specific aims are: (a) to study the content validity using a panel of experts; (b) to assess the stability of the questionnaire through Kendall's tau-b $(\tau \mathrm{b})$ correlation coefficient; (c) to corroborate the validity of the comprehension of the instrument through applying it to a pilot sample; (d) to determine the multidimensionality of the construct using exploratory factor analysis; (e) to confirm that multidimensionality of the construct using confirmatory factor analysis; (f) to analyse the reliability of the questionnaire; and (g) to show evidence of validity describing the opinions of the families and analysing the differences with respect to the variables studied.

\subsection{Instrument}

The literature review carried out by the research team showed the absence of specific instruments on inclusive leadership, which is why it was decided to create the LEI-Q questionnaire. For this purpose, on the one hand, the literature on inclusive leadership was analysed, and more specifically, the tasks/functions that the management team should carry out to promote inclusive policies, culture, and practices in their school. On the other hand, those items that were seen as suitable for measuring inclusive leadership were selected from questionnaires on inclusion or leadership in general. The research team, after analysing all this information, proceeded to determine the dimensions and items. The LEI-Q-Familia instrument uses a Likert scale with four responses. A Likert scale was chosen for the following reasons: it is an easy method to construct; it is quick and easy for the user to answer; it can be used in any format; it allows quality and easily quantifiable measures to be extracted; and it can be quickly compared with previous surveys to check 
the evolution of responses [30]. As can be seen in Appendix A, the responses are made according to the following scale:

1. Not yet implemented: there is no or very little evidence that the statement is correct in practice.

2. Partly implemented: there is some evidence that the statement is true in the school, but a series of practices need to improve.

3. Substantially implemented: there is good evidence that the statement is true in the school, but they are still actions that could improve it.

4. Fully implemented: there is good evidence that the statement is true in the school, and, therefore, it would be difficult to find ways to improve it.

It comprises 37 items distributed in two dimensions: "Openness to the community" (items 1-15, Dimension I), which analyses the initiatives of the management team to open the school up more to the community and the neighbourhood, and those initiatives that are aimed at overcoming situations that hinder the success of everyone and equality of opportunity; and "The school as an inclusive space" (items 16-37, Dimension II), which evaluates the actions undertaken by the management team to promote participation, deal with diversity, and prevent and manage conflicts in the school.

\subsection{Participants}

We opted for stratified random sampling. To calculate the sample size, we took into account an expected proportion of $66 \%$ (based on the data from the earlier pilot sample) and a precision of 5\% [30]. The sample needed for significance was established at 101 schools. These schools were in the city of Granada (Spain), 64 of them state schools and 37 charter schools (with public and private funding). Although all the schools were invited to participate, in the end 13 schools -8 state and 5 charter-responded, thus giving rise to a sampling that was purposive in nature. We adopted the following criteria: type of school (state, charter) and type of education (primary, secondary, and primary and secondary combined).

The number of families who completed the questionnaire was 150, of whom $66.7 \%$ $(\mathrm{N}=100)$ are women and $33.3 \%(\mathrm{~N}=50)$ men. Out of all the participants, 107 (74 women and $33 \mathrm{men}$ ) belonged to state schools, and 43 (26 women and $17 \mathrm{men}$ ) to charter schools. Fathers made up $32.7 \%(\mathrm{~N}=49)$, mothers $66 \%(\mathrm{~N}=99)$, while $1.3 \%(\mathrm{~N}=2)$ were legal guardians. The descriptive data about the participant families and the centres to which they belong can be seen in Table 1 .

\subsection{Procedure}

Our access to the families was undertaken with the prior authorization of the school administrations, which acted as intermediaries. The participants were informed of the purpose of the study, and confidentiality, anonymity, and data privacy were guaranteed [31]. The study duly received the proper authorization from the Ethics Committee of the University of Granada ( $\left.{ }^{\circ} 952 / \mathrm{CEIH} / 2019\right)$. The information was gathered in person via questionnaires on paper.

\subsection{Data Analysis}

The validation of the content was carried out using a panel of experts [31]. In order to analyse the metric properties of each item, the basic descriptive coefficients were used (mean, dispersion, kurtosis, and skewness). The validation of the construct was performed by means of exploratory factor analysis (EFA) — factor analysis version 10.10.01 [32]in order to determine the goodness of fit and the validity of the scale [33], while the confirmatory factor analysis (CFA) - M-PLUS — established the validity and reliability of the fit of the model [34]. The instrument's internal consistency was calculated using Cronbach's alpha and the split-half method. In order to determine whether the instrument provided valid information in accordance with its purpose, we carried out the MannWhitney U test (for the variables of gender, age, and type of school) and the Kruskal-Wallis 
test (for the variables of type of family connection, educational levels taught by the school, and socioeconomic level of the school's district). The aim was to define the groups between which significant differences were observed according to the variables studied. The results indicated that non-parametric statistics should be used, as the Kolmogorov-Smirnov test yielded results of less than 0.05. All analysis was done using SPSS 26.0.

Table 1. Sociodemographic and relational data of the participants.

\begin{tabular}{|c|c|c|}
\hline \multicolumn{2}{|c|}{ Variables } & $N=150$ \\
\hline \multirow{5}{*}{ Age } & Under 30 years old & $2(1.3 \%)$ \\
\hline & From 30 to 39 years & $40(26.7 \%)$ \\
\hline & From 40 to 49 years & $93(62 \%)$ \\
\hline & From 50 to 59 years & $15(10 \%)$ \\
\hline & Over 60 years & $0(0 \%)$ \\
\hline \multirow{3}{*}{ Gender } & Female & $100(66.7 \%)$ \\
\hline & Male & $50(33.3 \%)$ \\
\hline & Other & $0(0 \%)$ \\
\hline \multirow{3}{*}{ Type of family connection } & Father & $49(32.7 \%)$ \\
\hline & Mother & $99(66 \%)$ \\
\hline & Guardian & $2(1.3 \%)$ \\
\hline \multirow{2}{*}{ Type of school } & State & $103(68.6 \%)$ \\
\hline & Charter & $47(314 \%)$ \\
\hline \multirow{3}{*}{$\begin{array}{l}\text { Educational levels taught in } \\
\text { the school }\end{array}$} & Primary Education & $103(68.6 \%)$ \\
\hline & Secondary Education & $15(10 \%)$ \\
\hline & Primary and Secondary Education & $32(21.4 \%)$ \\
\hline \multirow{4}{*}{$\begin{array}{l}\text { Socioeconomic level in the } \\
\text { school's district }\end{array}$} & High & $1(0.6 \%)$ \\
\hline & Middle & $103(69.5 \%)$ \\
\hline & Middle-Low & $36(23.4 \%)$ \\
\hline & Low & $10(6.5 \%)$ \\
\hline
\end{tabular}

\section{Results}

\subsection{Content Validation}

A panel of experts was used to validate the content. This validation method is useful for verifying the validity of a survey [35]. In the content validation process of the questionnaire, 7 experts participated, with between 10 and 45 years of experience. Four of them are university professors, three are from the University of Granada, and one is from the University of Jaen. All are specialists in inclusive leadership, instrument assessment, and psychometry. The other three experts are state-school teachers in the city of Granada (one in primary education, two in secondary education). The experts validated the items according to the following criteria: clarity, degree of coherence with the dimension, and relevance regarding the subject of study, on a scale of 1 to 4 .

The degree of agreement between the experts was verified using the percentage of agreement, evaluated through the intraclass correlation coefficient (ICC), Kendall's coefficient, and Cronbach's alpha. The results obtained using the ICC were highly valid, with values of 0.957 . In the case of Kendall's coefficient, the values were significant, albeit low-0.203 (Dimension I) and 0.169 (Dimension II)—while for Cronbach's alpha, the results were 0.942 (Dimension I) and 0.962 (Dimension II), and thus excellent.

\subsection{Construct Validity}

Before undertaking the EFA, the descriptive values of the study were calculated (Table 2), following the steps recommended by Schmider [36], and, given that the dispersion tests (skewness and kurtosis) produced values outside of the -1.5 and +1.5 range [37], in some items, we therefore removed items 18, 23, 24, 27, 29, and 37. The items had mean values between 3.43 (V24) and 2.36 (V06). The SDs were close to 1, indicating a greater variability of participant opinion. 
Table 2. Description of the items of the Inclusive Leadership in Schools questionnaire (LEI-Q-Family).

\begin{tabular}{|c|c|c|c|c|}
\hline Variables & Mean & Standard Deviation & Skewness & Kurtosis \\
\hline V01 & 3.08 & 0.867 & -0.822 & 0.462 \\
\hline V02 & 2.99 & 0.886 & -0.661 & 0.083 \\
\hline V03 & 2.06 & 1.046 & 0.147 & -0.667 \\
\hline V04 & 2.49 & 1.116 & -0.355 & -0.729 \\
\hline V05 & 3.03 & 1.116 & -0.999 & 0.558 \\
\hline V06 & 2.36 & 1.096 & -0.009 & -0.917 \\
\hline V07 & 2.79 & 0.956 & -0.375 & -0.576 \\
\hline V08 & 3.12 & 0.935 & -0.867 & 0.092 \\
\hline V09 & 2.93 & 1.073 & -0.724 & -0.226 \\
\hline V10 & 2.79 & 0.977 & -0.239 & -0.821 \\
\hline V11 & 3.10 & 0.864 & -0.572 & -0.580 \\
\hline V12 & 2.62 & 1.023 & -0.636 & 0.189 \\
\hline V13 & 3.11 & 0.882 & -0.739 & 0.059 \\
\hline V14 & 2.81 & 1.046 & -0.655 & -0.045 \\
\hline V15 & 2.72 & 1.006 & -0.272 & -0.842 \\
\hline V16 & 2.49 & 1.127 & -0.494 & -0.393 \\
\hline V17 & 3.30 & 0.801 & -1.057 & 0.703 \\
\hline V18 & 3.15 & 0.846 & -1.143 & 1.775 \\
\hline V19 & 3.06 & 0.865 & -0.543 & -0.521 \\
\hline V20 & 3.25 & 0.813 & -1.015 & 1.030 \\
\hline V21 & 2.84 & 1.051 & -1.073 & 1.022 \\
\hline V22 & 3.03 & 0.932 & -0.900 & 0.750 \\
\hline V23 & 3.43 & 0.774 & -1.427 & 2.260 \\
\hline V24 & 3.21 & 1.141 & -1.646 & 1.958 \\
\hline V25 & 2.73 & 1.294 & -0.959 & -0.111 \\
\hline V26 & 2.84 & 1.109 & -0.764 & -0.230 \\
\hline V27 & 3.11 & 1.070 & -1.391 & 1.619 \\
\hline V28 & 2.81 & 1.042 & -0.865 & 0.645 \\
\hline V29 & 3.06 & 1.095 & -1463 & 1.781 \\
\hline V30 & 2.85 & 1.021 & -0.814 & 0.336 \\
\hline V31 & 2.62 & 1.161 & -0.681 & -0.232 \\
\hline V32 & 2.99 & 1.060 & -1.107 & 0.779 \\
\hline V33 & 2.66 & 1.127 & -0.661 & -0.165 \\
\hline V34 & 2.75 & 1.169 & -0.761 & -0.222 \\
\hline V35 & 2.88 & 1.072 & -0.989 & 0.548 \\
\hline V36 & 3.10 & 0.948 & -0.849 & 0.219 \\
\hline V37 & 3.35 & 0.837 & -1.621 & 3.182 \\
\hline
\end{tabular}

Note: $\mathrm{N}=150$.

For the EFA, we used the parallel analysis (PA) method with prominent rotation to maximize the simplicity of the factors, determining two factors, as is recommended for PA [38]. Bartlett's test statistic [1632.9 ( $\mathrm{df}=465 ; p=0.000010)]$ and the Kaiser-Meyer-Olkin test $(\mathrm{KMO})[=0.905]$ were used to check whether the sample came from populations with the same variance and whether it had an adequate fit. It showed a good fit with the data to be subjected to factor analysis. The two obtained factors explained $47 \%$ of the total variance. The goodness of fit index (GFI) was 0.983, the adjusted goodness of fit index (AGFI) gave a value of 0.980 , the comparative fit index (CFI) was 1.00, and the root mean square residuals (RMSR) obtained a value of 0.0236, with the expected mean value of RMSR being an acceptable 0.0585 , as per Kelly [39]. The reliability of Factor 1 was 0.934 and Factor 20.949. All these data indicate an excellent fit of these items and an acceptable model.

As can be seen in the rotated factor matrix (Table 3), all the items (V05, V07, V12, V22, and V30) with weights with an absolute value lower than 0.40 were eliminated [40]. Thus, having analysed and evaluated the weight of each variable according to the factor, the questionnaire was finalized as follows: Factor 1: "The school as an inclusive space" with 12 items (V3, V4, V6, V16, V25, V26, V28, V31, V32, V33, V34, and V35), and Factor 2: 
"Openness to the community" with 14 items (V1, V2, V8, V9, V10, V11, V13, V14, V15, V17, V19, V20, V21, and V36).

Table 3. Rotated factor matrix LEI-Q (families).

\begin{tabular}{|c|c|c|}
\hline Variables & F1 & F2 \\
\hline V01 & & 0.958 \\
\hline V02 & & 1.005 \\
\hline V03 & 0.960 & \\
\hline V04 & 0.500 & \\
\hline V05 & 0.166 & 0.265 \\
\hline V06 & 0.617 & \\
\hline V07 & 0.231 & 0.348 \\
\hline V08 & & 0.737 \\
\hline V09 & & 0.647 \\
\hline V10 & & 0.585 \\
\hline V11 & & 0.924 \\
\hline V12 & 0.328 & 0.212 \\
\hline V13 & & 0.744 \\
\hline V14 & & 0.595 \\
\hline V15 & & 0.584 \\
\hline V16 & 0.637 & \\
\hline V17 & & 0.724 \\
\hline \multicolumn{3}{|l|}{ V18 } \\
\hline V19 & & 0.677 \\
\hline V20 & & 0.949 \\
\hline V21 & & 0.403 \\
\hline V22 & 0.335 & 0.279 \\
\hline \multicolumn{3}{|l|}{ V23 } \\
\hline \multicolumn{3}{|l|}{ V24 } \\
\hline V25 & 0.778 & \\
\hline V26 & 0.444 & \\
\hline \multicolumn{3}{|l|}{ V27 } \\
\hline V28 & 0.417 & \\
\hline \multicolumn{3}{|l|}{ V29 } \\
\hline V30 & 0.315 & 0.356 \\
\hline V31 & 0.681 & \\
\hline V32 & 0.579 & \\
\hline V33 & 1.120 & \\
\hline V34 & 0.769 & \\
\hline V35 & 0.535 & \\
\hline V36 & & 0.635 \\
\hline V37 & & \\
\hline
\end{tabular}

Authors such as Carretero-Dios and Pérez [41] and Clark and Watson [42] recommend conducting a correlational study to ensure the homogeneity of each dimension. The correlational analysis of the final version of the scale produced significant results at the 0.01 levels (two-tailed). The correlation between the score of each item and the total score in each component shows a positive correlation with the corresponding theoretical dimension and with the total score of the other dimension. The values obtained for each item of Factor 1 varied between $r=0.808 p<0.000$ and $r=0.645, p<0.000$, and, for Factor 2, between $\mathrm{r}=0.284 p<0.000$ and $\mathrm{r}=0.852 p<0.000$. The two factors show a very good relationship $(\mathrm{r}=0.847 p<0.000)$.

\subsection{Confirmatory Factor Analysis}

With the aim of testing the model by means of EFA for the families, we carried out a confirmatory analysis through M-PLUS, with the structure we constructed being as follows (Figure 1): 


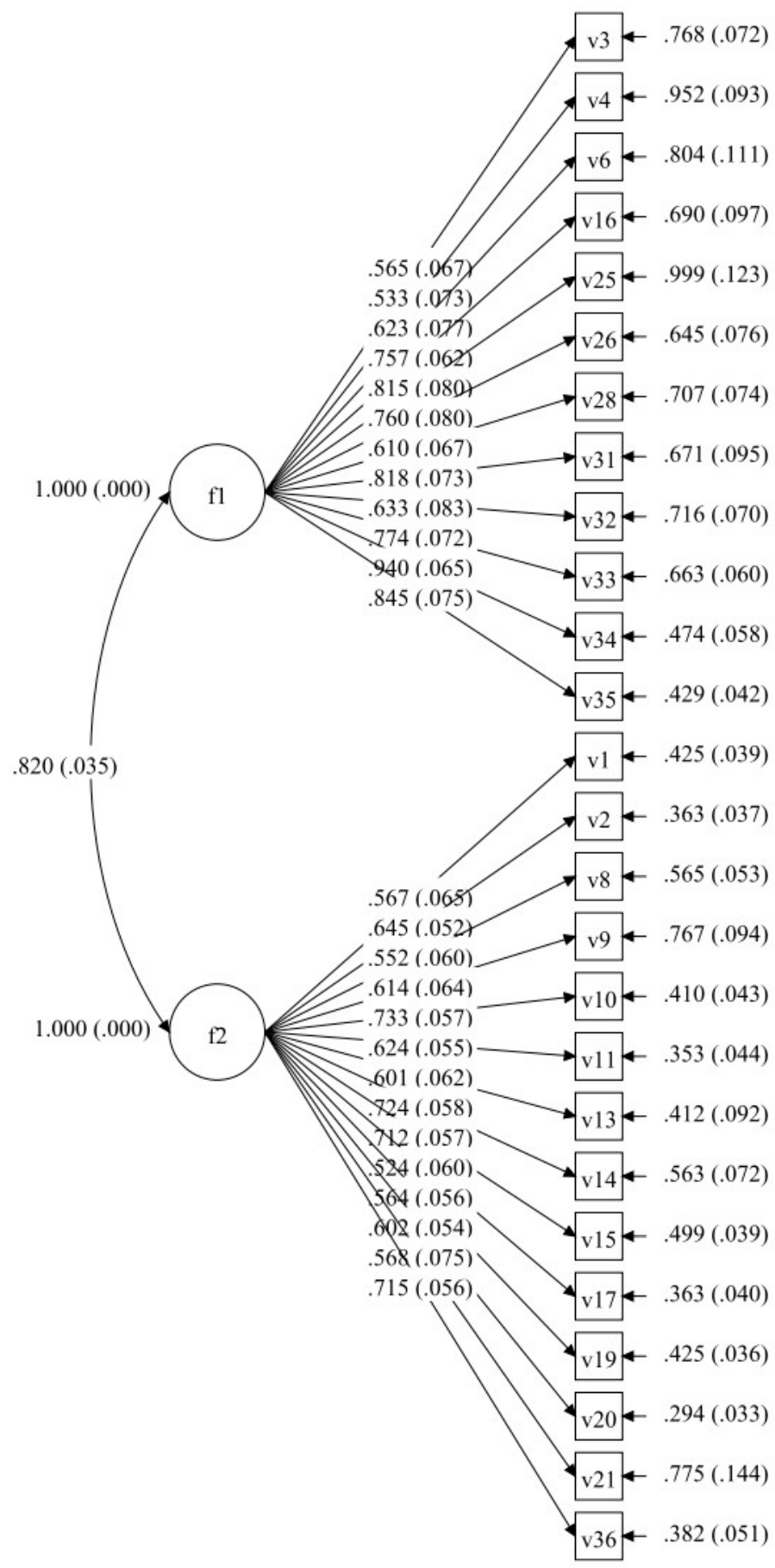

Figure 1. Model theories. Note: F1, Openness to the community; F2, The school as inclusive space. $\mathrm{N}=150$.

The final structural model we obtained confirmed the existence of two factors: F1, consisting of 12 items (v3, v4, v6, v16, v25, v26, v28, v31, v32, v33, v34, v35), and F2, comprising 14 items (v1, v2, v8, v9, v10, v11, v13, v14, v15, v17, v19, v20, v21, v36). The results obtained via M-PLUS indicate a good model fit [43], with the values attained being favourable and acceptable for the RMSEA (0.058), CFI (Comparative Fit Index was 0.903, for the SRMR, (0.061)), and the TLI (Tucker-Lewis Index) at 0.895. Furthermore, for these indices of fit, it is important for the CFA to provide composite reliability (CR) data [42] for each critical dimension. This makes it possible to analyse the relations between the responses to the items and the latent variable measure [44], as well as the average variable 
extracted (AVE) [45] in order to study the validity of the scale. The CR value should be higher than 0.70 and the AVE should be above 0.50 [43]. The CR for Factor 1 was 0.89 and the AVE 0.53, while for Factor 2 the CR attained the value of 0.91 and the AVE 0.40.

\subsection{Reliability Calculation}

The methods for calculating reliability that we chose are Cronbach's alpha and the splithalf method, which are highly used in social research [46,47]. The reliability coefficient of the whole of the questionnaire was 0.944 , obtained with a confidence level of $95 \%$ $(p<0.05)$, while Factor 1 obtained 0.897 (with 12 elements) and Factor 2 (with 14 elements) attained 0.920 .

For the Spearman Brown coefficient, the result obtained was 0.861. The first split-half, comprising 13 items, attained a value of 0.912 , and the second split-half, with the other 13 items, was 0.905 .

\subsection{Description of the Dimensions: "Openness to the Community" and "The School as Inclusive Space"}

The results derived from the descriptive analysis and the differential analysis were done by dimensions (the mean of the set of items that comprises each dimension). The responses given by the families of the participating schools regarding the actions carried out by the school management teams (Table 4 ) indicate that these teams have substantially implemented $(\mathrm{M}=3.01)$ the actions aimed at improving the school's openness to the community and the neighbourhood, at the same time as establishing measures for solving the situations that hinder the success of everyone and equality of opportunity (sports activities, talks against racism, etc.). More specifically, the families highlight the most implemented actions as those aimed at: counteracting the negative influence that a family's situation might have on student success; providing material and human resources (specific professionals); undertaking activities of interest to the community alongside other institutions/organizations; promoting the communication and participation of all families in the activities undertaken inside and outside the school; making families aware of the importance and benefits of inclusion; and fostering a shared vision and common educational project among the teachers and education community.

Table 4. Description of the dimensions: "Openness to the community" and "The school as inclusive space".

\begin{tabular}{ccc}
\hline Dimension & & \\
\hline & $\mathrm{M}$ & $\mathrm{SD}$ \\
Openness to the community & 3.01 & 0.653 \\
The school as inclusive space & 2.64 & 0.767 \\
\hline Note: $\mathrm{M}=\mathrm{Mean}$ SD $=$ Standard deviation
\end{tabular}

Note: $\mathrm{M}=$ Mean; $\mathrm{SD}=$ Standard deviation.

However, within this first dimension, the families consider that the management teams have been less committed in promoting the mutual understanding, exchanges, and coming together between the families and the other members of the schools. They have also been remiss at informing the families, through different communication channels, of the curriculum that guides the educational work of a school, and they fail to listen and take into consideration the demands and needs of all families.

In terms of the actions adopted to make schools an inclusive space, the families believe that those actions that the management carries out to encourage participation, deal with diversity, and prevent and manage conflicts in the school are only partly implemented $(\mathrm{M}=2.64)$ in their schools, and hence demand greater action. Among the most implemented, they mention the following: guaranteeing equality of opportunities by mobilizing resources (material and human); enabling the students to freely express their opinion and needs to promote actions for the care of all students; facilitating the participation of the students in the governing bodies of the school; and developing measures to prevent and avoid truancy. 
The actions of this dimension that are least implemented are the following: to establish disciplinary measures against the use of symbols and actions that encourage exclusion; to share authority and responsibility with teachers; and to create opportunities so that all members of the education community participate in decision making.

\subsection{Differences According to the Study's Identifying Variables}

From the Mann-Whitney U test and the Kruskal-Wallis test, we obtained statistically significant differences only in the following variables: type of school (state or charter) and the educational levels it teaches (primary education, secondary education, or both combined).

\subsubsection{Differences According to School Type}

This variable shows statistically significant differences in the two dimensions. The charter schools have higher scores than the state schools in both dimensions. In this regard, the families of the charter schools perceive that the management teams have achieved greater implementation of initiatives aimed at making the school more open to the community and neighbourhood, overcoming situations that impede the success of everyone and equality of opportunity, promoting participation, dealing with diversity, and preventing and managing conflicts in the school (Table 5).

Table 5. Mann-Whitney U test according to school type.

\begin{tabular}{|c|c|c|c|c|c|c|c|}
\hline & \multicolumn{2}{|c|}{ State $(n=103)$} & \multicolumn{2}{|c|}{ Charter $(n=47)$} & \multirow{2}{*}{$\mathbf{U}$} & \multirow{2}{*}{$\mathrm{Z}$} & \multirow{2}{*}{$p$} \\
\hline & $\mathbf{M}$ & SD & $\mathbf{M}$ & SD & & & \\
\hline Openness to the community & 2.93 & 0.587 & 3.26 & 0.646 & 1642.000 & -3.426 & 0.001 * \\
\hline The school as inclusive space & 2.66 & 0.787 & 3.18 & 0.777 & 1481.000 & -4.060 & 0.000 * \\
\hline
\end{tabular}

Note: $\mathrm{M}=$ Mean; $\mathrm{SD}=$ Standard deviation; ${ }^{*}$ = significant at 0.05 .

3.6.2. Differences According to the Educational Levels Taught at the School

There are statistically significant differences with regard to the educational levels taught by the school: the management teams of the schools that teach both primary and secondary education are those that, according to the families, have better implemented the initiatives that make the school more open to the community and neighbourhood, increase participation, and manage diversity and prevent and handle conflicts in the school (Table 6).

Table 6. Kruskal-Wallis test according to educational levels taught.

\begin{tabular}{cccccccccc}
\hline & \multicolumn{2}{c}{ Primary } & \multicolumn{2}{c}{ Secondary } & \multicolumn{2}{c}{ Primary and Secondary } & \multirow{2}{*}{$\chi^{2}$} & df & $\boldsymbol{p}$ \\
\cline { 2 - 7 } & $\mathbf{M}$ & SD & $\mathbf{M}$ & SD & $\mathbf{M}$ & SD & & \\
\hline Openness to the community & 2.95 & 0.632 & 2.88 & 0.567 & 3.40 & 0.478 & 14.748 & 2 & 0.001 \\
The school as inclusive space & 2.67 & 0.828 & 2.86 & 0.676 & 3.28 & 0.670 & 16.241 & 2 & 0.000 \\
\hline
\end{tabular}

Note: $\mathrm{M}=$ Mean; $\mathrm{SD}=$ Standard deviation.

\section{Discussion and Conclusions}

The main aim of the study was to design and validate the instrument, "Leading inclusive education in compulsory-education schools" (LEI-Q-families). The instrument was constructed to determine the perception of families regarding the degree to which the school leadership promotes the inclusion and learning of all students.

Having analysed the validity of the content, of the construct (EFA and CFA), and of the reliability of the questionnaire, we can affirm that the questionnaire aimed at families is valid and reliable for measuring the inclusive leadership of the teams that run schools of compulsory education in Spain from the perspective of families [35,48,49].

The result of the statistical analysis of the items and of the EFA shows the existence of two factors that indicated an excellent fit of these items and an acceptable model. 
In order to test the factorial structure of the questionnaire, made up of 2 factors and 26 items, we carried out a CFA using M-PLUS, obtaining favourable values. These indicate a good model fit [43].

The results obtained were satisfactory with regard to the Cronbach's alpha coefficients, both for the questionnaire as a whole and for its two factors. The internal consistency of the extracted factors can be considered highly reliable $[37,46,50]$.

Although Cronbach's alpha is the most used reliability coefficient in social sciences [45], some authors $[51,52]$ state that it is a biased statistic. We have therefore calculated the composite reliability, thus confirming the reliability and capacity of the instrument to measure inclusive leadership. Following the validation process, LEI-Q-Families consists of Dimension I (according to CFA Factor II), Openness to the community (V01, V02, V08, V09, V10, V11, V13, V14, V15, V17, V19, V20, V21, and V36), and Dimension II (according to CFA Factor I), The school as inclusive space (V03, V04, V06, V16, V25, V26, V28, V31, $\mathrm{V} 32, \mathrm{~V} 33, \mathrm{~V} 34, \mathrm{~V} 35)$. After a review of the organisation of the items obtained based on the CFA, taking into account the objective of the study and the literature reviewed, the final version is shown in Appendix B. The descriptive analysis shows that the families believe that the actions that form part of the dimension of openness to the community are substantially implemented, while those that concern the dimension of the school as an inclusive space are only partly so. The families have a positive view, however, regarding the actions undertaken by school management with regard to the openness of the school to the community. These actions are concerned with the need to counteract the negative influence a family's situation might have on student success, improving their participation in activities inside and outside the school, and contributing to increasing awareness on the importance and benefits of inclusion [53]. However, there is still much work to be done, as the results show that not all actions are implemented by the management team. Greater commitment is needed, therefore, from the management teams in order to achieve inclusion $[18,19,53]$. School managers should take on the extra contribution that comes from the integration of families and other agents from the neighbourhood to improve education, inclusion, and the school itself $[1,11,15,26]$.

Regarding the opinion of the families on the actions most implemented by the management team to foster an inclusive school, the study shows that there are none with respect to the families and/or the educational community in general. This absence reflects the scant presence of families and the lack of attention afforded them and the education community by the school managers in the processes aimed at turning schools into inclusive spaces. This fact, undoubtedly paradoxical given that it concerns the effort to promote inclusion, should be the cause for reflection by school managers, since all families have a right to participate actively in the decision making that affects schools and impacts the education of their children $[4,5]$.

Lastly, the study has revealed that there are significant differences in the families as a function of the educational level taught by the schools, and the type of school. The families of the schools that teach both primary and secondary education and are charter schools are those who most highly rate the actions undertaken by the management teams to open up more to the community (Dimension I) and to turn the schools into inclusive spaces (Dimension II). The fact that it is the families from charter schools (funded publicly and privately) who most highly rate the inclusive actions undertaken by school management may be connected to the need this type of school has to maintain its status quo, offering a differentiated education that guarantees high levels of enrolment. This pragmatic outlook, closely linked to the concern to keep up the social image of the school, is an issue that affects the decisions taken by school leaders and the actions they undertake to promote inclusion, as Poon-McBrayer [24] and Szeto and Cheng [25] have recognized.

This type of study is particularly relevant in that it focuses its attention on a key factor for improving inclusion in schools: the practices implemented by school management. Furthermore, it provides a valid and reliable instrument that makes the participation of families possible in the creation of inclusive schools and helps to increase the limited 
knowledge that currently exists on the real contribution of school managers to the processes of inclusion from perspectives other than those of teachers and the school managers themselves. However, this research has some limitations related to the sample size and its representativeness (non-probability and limited to a specific context at a specific moment in time). It would be worthwhile to broaden the research with other experimental studies using probability sampling or longitudinal studies that would make it possible to analyse the evolution experienced in the perceptions of families on the inclusive leadership carried out by school management. Not having the opinion of families in the design and validation of the questionnaire items can be seen as another limitation.

Author Contributions: Conceptualization, all authors; Methodology, all authors; Validation, E.C.M.; Formal Analysis, E.C.M.; Investigation, all authors; Data Curation, E.C.M.; Writing—original draft preparation, all authors; Writing-Review and Editing, all authors; Visualization, all authors. All authors have read and agreed to the published version of the manuscript.

Funding: This research was funded by the European Regional Development Fund (ERDF) and the Junta of Andalusia in Spain (Ref: B-SEJ-057-UGR18).

Informed Consent Statement: Informed consent was obtained from all subjects involved in the study.

Data Availability Statement: The data presented in this study are available on request from the Corresponding author.

Conflicts of Interest: The authors declare no conflict of interest.

\section{Appendix A}

Table A1. Version presented to participants: LEI-Q "leading inclusive education in compulsory education schools"-families.

The questionnaire "INCLUSIVE LEADERSHIP IN PRIMARY AND SECONDARY SCHOOLS" is a tool that enables the evaluation of the degree to which the leadership of school management teams favours the inclusion and learning of all students. The instrument is structured around TWO dimensions:

DIMENSION 1: Openness to the Community. The management team carries out initiatives that increase the school's openness to the community and neighbourhood, at the same time as establishing measures aimed at overcoming situations that hinder the success of all students and equality of opportunity.

DIMENSION 2: The school as inclusive space. The management team undertakes actions to promote participation, manage diversity and prevent and handle conflict in the institution.

The responses should be made according to the following scale:

Not yet implemented: there is no or very little evidence that the statement is correct in practice.

Partly implemented: there is some evidence that the statement is true in the school, but a series of practices need to improve.

Substantially implemented: there is good evidence that the statement is true in the school, but they are still actions that could improve it.

Fully implemented: there is good evidence that the statement is true in the school, and, therefore, it would be difficult to find ways to improve it.

\begin{tabular}{cl}
\hline Variable & \multicolumn{1}{c}{ Items } \\
\hline V01 & $\begin{array}{l}\text { Advances initiatives that favour the participation of community members in the education process and in the life of } \\
\text { the school }\end{array}$ \\
\hline V02 & $\begin{array}{l}\text { Establishes an action plan drawn up in collaboration with other members of the community to foster relationships } \\
\text { between the school and community and to manage student diversity }\end{array}$ \\
\hline V03 & $\begin{array}{l}\text { Offers transparent information regarding the admission process and enrolment to guarantee that it reaches all interested } \\
\text { parties equally }\end{array}$ \\
\hline V04 & Takes measures to prevent and avoid truancy \\
\hline V05 & Proposes educational activities outside the school \\
\hline V06 & Shares authority and responsibility with teachers \\
\hline
\end{tabular}


Table A1. Cont.

\begin{tabular}{|c|c|}
\hline V07 & Promotes activities that promote mutual understanding among the school's students \\
\hline V08 & $\begin{array}{l}\text { Makes the school's facilities and resources available for activities (cultural, educational, etc.) that are of interest to } \\
\text { the community }\end{array}$ \\
\hline V09 & $\begin{array}{l}\text { Informs the family, through different channels of communication, of the curriculum that guides the school's } \\
\text { educational activities }\end{array}$ \\
\hline V10 & Promotes actions to increase family awareness of the importance and benefits of inclusion \\
\hline V11 & $\begin{array}{l}\text { Promotes actions that enable the communication and participation of all families in the educational activities } \\
\text { undertaken inside and outside the school }\end{array}$ \\
\hline V12 & $\begin{array}{l}\text { Establishes actions that promote the real representation of the diversity of existing families in the school's } \\
\text { governing bodies }\end{array}$ \\
\hline V13 & Listen to and take into account the needs and demands of all families \\
\hline V14 & $\begin{array}{l}\text { Promote activities that enhance the mutual knowledge, exchange, and coming together of both the families and the } \\
\text { members of the school }\end{array}$ \\
\hline V15 & $\begin{array}{l}\text { Sets up measures to counteract the negative influence that a family situation might have on student success (support } \\
\text { campaigns, learning assistance, school for parents, etc.) }\end{array}$ \\
\hline V16 & Ensures that equal opportunities are guaranteed, mobilizing resources (material and human) in order to foster inclusion \\
\hline V17 & $\begin{array}{l}\text { Ensures that the services offered by the school respect the different needs of the students (religious sensitivities, food } \\
\text { intolerances, health problems, etc.) }\end{array}$ \\
\hline V18 & It has a procedure for collecting information on the needs of teachers, students and other school staff \\
\hline V19 & Ensures that the school has material and human (specific professionals) resources to promote improvement processes \\
\hline V20 & Works to obtain a school climate in which all students are recognized, cared for, and valued \\
\hline V21 & $\begin{array}{l}\text { Fosters a shared outlook between teachers and educational community on the organization, goals, and activities in } \\
\text { order to make them participants in a common educational project }\end{array}$ \\
\hline V22 & $\begin{array}{l}\text { It establishes protocols for dealing with conflicts through dialogue, mediation, and negotiation between the } \\
\text { parties involved }\end{array}$ \\
\hline V23 & $\begin{array}{l}\text { It promotes collaboration with the business world on an ongoing basis to strengthen the school-work } \\
\text { environment relationship }\end{array}$ \\
\hline V24 & Promotes actions to collaborate with other educational centres to know and share experiences \\
\hline V25 & Establishes disciplinary measures against the use of symbols and actions that encourage exclusion \\
\hline V26 & Develops educational programmes to prevent discriminatory attitude among students \\
\hline V27 & Organises debates open to the community on situations of exclusion (racism, xenophobia, sexism, etc.) \\
\hline V28 & Creates opportunities for all members of the education community to participate effectively in decisions \\
\hline V29 & It establishes procedures in order to promote the improvement of the centre \\
\hline V30 & It has mechanisms in place to document changes and improvements undertaken \\
\hline V31 & $\begin{array}{l}\text { Makes it possible for the different members of the education community to participate in the evaluation of the } \\
\text { management's work }\end{array}$ \\
\hline V32 & Promotes actions to care for all students \\
\hline V33 & Encourages the participation of students in the school's governing bodies \\
\hline V34 & Establishes mechanisms to promote student participation in the control of conflicts that arise in the school environment \\
\hline V35 & $\begin{array}{l}\text { Enable students to express their opinions and needs freely (with regard to the education process, rules, and the running } \\
\text { of the school, etc.) }\end{array}$ \\
\hline V36 & $\begin{array}{l}\text { Participates in the actions undertaken by other institutions/organizations of the community that are educational in } \\
\text { nature (sports activities, events against racism, etc.) }\end{array}$ \\
\hline V37 & It is concerned with guaranteeing access to the school's facilities and services for all students \\
\hline
\end{tabular}




\section{Appendix B}

Table A2. Final version LEI-Q “leading inclusive education in compulsory education schools"—families.

DIMENSION 1: Openness to the Community. The management team carries out initiatives that increase the school's openness to the community and neighbourhood, at the same time as establishing measures aimed at overcoming situations that hinder the success of all students and equality of opportunity.

DIMENSION 2: The school as inclusive space. The management team undertakes actions to promote participation, manage diversity and prevent and handle conflict in the institution.

The responses should be made according to the following scale:

1. Not yet implemented: there is no or very little evidence that the statement is correct in practice.

2. Partly implemented: there is some evidence that the statement is true in the school, but a series of practices need to improve.

3. Substantially implemented: there is good evidence that the statement is true in the school, but they are still actions that could improve it.

Fully implemented: there is good evidence that the statement is true in the school, and, therefore, it would be difficult to find ways to improve it.

\begin{tabular}{cllll}
$\begin{array}{c}\text { List to According } \\
\text { CFA }\end{array}$ & DIMENSION 1: OPENNESS TO THE COMMUNITY & & 1 & 2 \\
\hline
\end{tabular}

1. please change the table into a figure or box Advances initiatives that favour the

V01 participation of community members in the education process and in the life of the school

2. $\begin{aligned} & \text { please change the table into a figure or boxEstablishes an action plan drawn up in } \\ & \text { collaboration with other members of the community to foster relationships between the } \\ & \text { school and community and to manage student diversity }\end{aligned}$
V02

V36 3. Participates in the actions undertaken by other institutions/organizations of the community that are educational in nature (sports activities, events against racism, ... )

V08 4. Makes the school's facilities and resources available for activities (cultural, educational, etc.) that are of interest to the community

V09 5. Informs the family, through different channels of communication, of the curriculum that guides the school's educational activities

V10 6 Promotes actions to increase family awareness of the importance and benefits of inclusion

V11 7. Promotes actions that enable the communication and participation of all families in the educational activities undertaken inside and outside the school

V13 Listen to and take into account the needs and demands of all families

V14 9. Promote activities that enhance the mutual knowledge, exchange, and coming together of both the families and the members of the school

V15 10. Sets up measures to counteract the negative influence that a family situation might have on student success (support campaigns, learning assistance, school for parents, etc.)

11. Ensures that the services offered by the school respect the different needs of the students (religious sensitivities, food intolerances, health problems, etc.) 
Table A2. Cont.

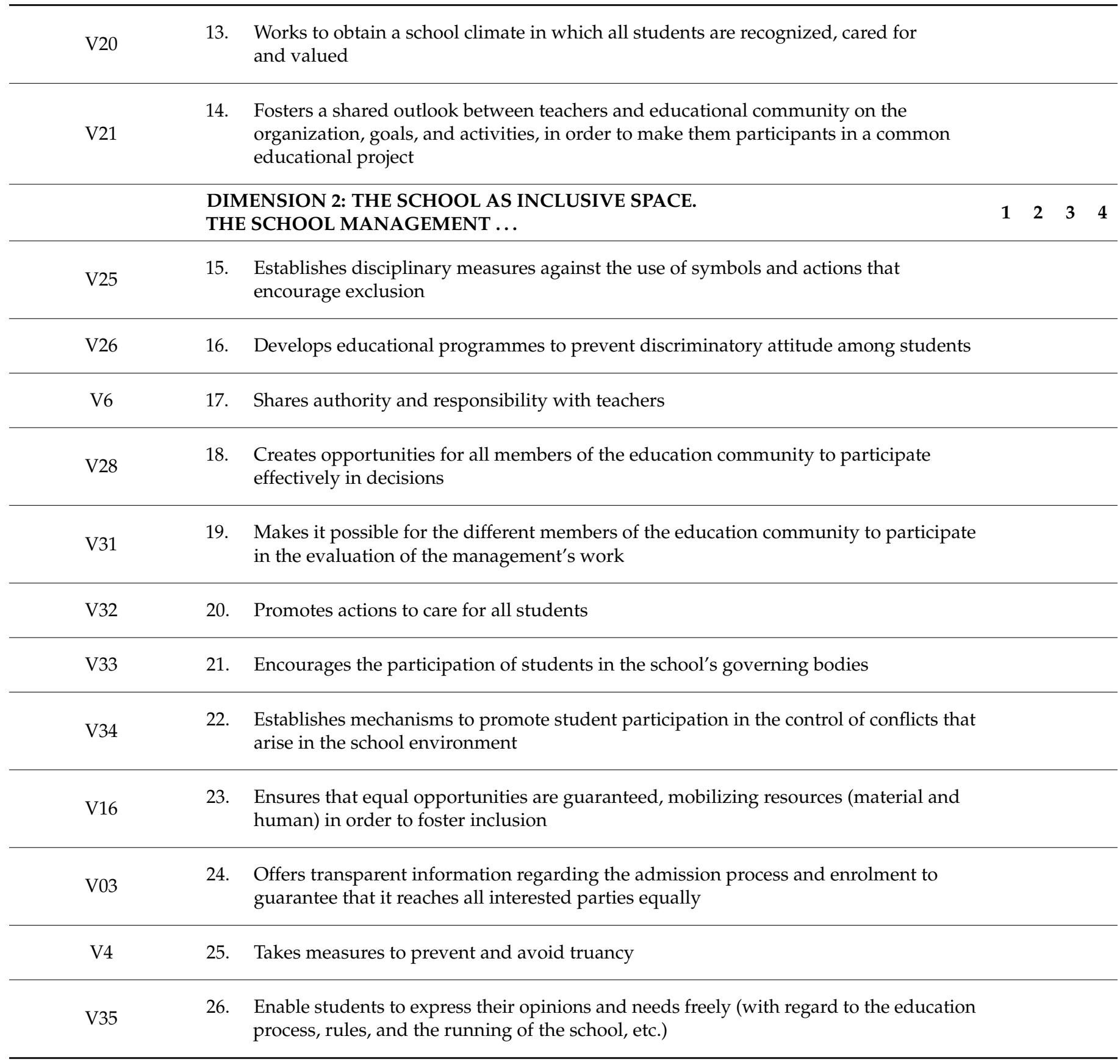

\section{References}

1. Barrientos, C.; Silva, P.; Antúnez, S. El papel directivo y la promoción de la participación de las families y la comunidad en las escuelas básica. El caso de la Comuna de Panguipulli-Chile. Efic. Y Cambio En Educ. 2016, 14, 145-165. [CrossRef]

2. Kiyama, J.M.; Harper, C.E. First-generation students and their families: Institutional responsibility during college access and transition. In Clearing the Path: Qualitative Studies of the Experience of First-Generation College Students; Lexington Press: Boston, MA, USA, 2018; pp. 1-5.

3. Liang, X.M.; Cohrssen, C. Towards creating inclusive environments for LGBTIQ-parented families in early childhood education and care settings: A review of the literature. Aust. J. Early Child. 2020, 45, 43-55. [CrossRef]

4. Okoko, J.M. Towards school leadership development: The essence of working with culturally and linguistically diverse newcomer families in Saskatchewan. Res. Educ. Adm. Leadersh. 2019, 4, 195-229. [CrossRef]

5. PNUD. Transformar Nuestro Mundo: La Agenda 2030 Para el Desarrollo Sostenible; PNUD: New York, NY, USA, 2015. Available online: http:/ / unctad.org/meetings/es/SessionalDocuments/ares70d1_es.pdf (accessed on 17 July 2021). 
6. UNESCO Educación 2030. Declaración de Incheon y Marco de Acción Para la Realización del Objetivo de Desarrollo Sostenible 4. Garantizar una Educación Inclusiva y Equitativa de Calidad y Promover Oportunidades de Aprendizaje Permanente Para Todos. 2016. Available online: http:/ / unesdoc.unesco.org/images/0024/002456/245656s.pdf (accessed on 17 July 2021).

7. Collet, J.; Tort, A. Escuela, Families y Comunidad; Octaedro: Barcelona, Spain, 2017.

8. Guiffrida, D.A.; Kiyama, J.M.; Waterman, S.J.; Museus, S.D. Moving from cultures of individualism to cultures of collectivism to serve college students of color. In Creating Campus Cultures That Foster Success among Racially Diverse Student Populations; Museus, S.D., Jayakumar, U.M., Eds.; Routledge: New York, NY, USA, 2012; pp. 68-87.

9. Hehir, T.; Grindal, T.; Freeman, B.; Lamoreau, R.; Borquaye, Y.; Burke, S. A Summary of the Evidence on Inclusive Education; Alana ABT: São Paulo, Brazil, 2016.

10. Mara, D.; Mara, E.L.; Andrei, O.; Danciu, E.L. The Role of School-Family Partnership in the Implementation of Inclusive Education in Romania. New Educ. Rev. 2011, 26, 228-237.

11. Stivers, J.; Latonya, F.; Straus, M. Educating families about inclusive education-A month-by-month guide for teachers of inclusive classes. Interv. Sch. Clin. 2008, 44, 10-17. [CrossRef]

12. Ainscow, M.; Dyson, A.; Hopwood, L.; Thomson, S. Primary Schools Responding to Diversity: Barriers and Possibilities; Cambridge Primary Review Trust: York, UK, 2016.

13. Simón, C.; Barrios, A. Las families en el corazón de la educación inclusiva. Aula Abierta 2019, 48, 51-58. [CrossRef]

14. Ryan, J. Struggling for Inclusion: Educational Leadership in a Neo-Liberal World; Issues in the Research, Theory, Policy, and Practice of Urban Education; Information Age Publishing: New York, NY, USA, 2012.

15. Wang, F. Social Justice Leadership-Theory and Practice: A Case of Ontario. Educ. Adm. Q. 2018, 54, 470-498. [CrossRef]

16. Valdés, R.A. Liderazgo inclusivo: La importancia de los equipos directivos en el desarrollo de una cultura de la inclusión. Rev. Investig. Educat. Rediech. 2018, 9, 51-65.

17. Harris, J.; Carrington, S.; Ainscow, M. Promoting Equity in Schools: Collaboration, Inquiry and Ethical Leadership; Routledge: Abingdon, UK, 2017.

18. Grant, K.B.; Ray, J.A. Home, School and Community Collaboration: Culturally Responsive Family Engagement; Sage Publications Thousand: Oaks, CA, USA, 2019.

19. Shields, C.M. Transformative Leadership in Education: Equitable Change in an Uncertain and Complex World; Routledge: New York, NY, USA, 2013.

20. Boscardin, M.L.; Shepherd, K.G. Leadership for evaluations responsive to disability and culture. J. Educ. Adm. 2020, 58, 555-570. [CrossRef]

21. Celoria, D. The preparation of inclusive social justice education leaders. Educ. Leadersh. Adm. Teach. Program Dev. 2016, 27, 199-219.

22. León, M.J.; López, M.C. La Formación del Líder Inclusivo. In Perspectivas Psicológicas y Educativas de las Necesidades Educativas Especiales; Nuñez, J.C., Ed.; Scinfoper: Granada, Spain, 2017; pp. 215-223.

23. Poon-McBrayer, K.F. School leaders' dilemmas and measures to instigate changes for inclusive education in Hong Kong. J. Educ. Chang. 2017, 18, 295-309. [CrossRef]

24. Szeto, E.; Cheng, A.Y.N. How do principals practice leadership for social justice in diverse school settings? A Hong Kong case study. J. Educ. Adm. 2018, 56, 50-68. [CrossRef]

25. Kiyama, J.M.; Harper, C.E. Beyond Hovering: A Conceptual Argument for an Inclusive Model of Family Engagement in Higher Education. Rev. High. Educ. 2018, 41, 365-385. [CrossRef]

26. Cardno, C.; Handjani, M.; Howse, J. Leadership Practices and Challenges in Managing Diversity to Achieve Ethnic Inclusion in Two New Zealand Secondary Schools. N. Z. J. Educ. Stud. 2018, 53, 101-117. [CrossRef]

27. Woodcock, S.; Woolfon, L. Are leaders leading the way with inclusion? Teachers' perceptions of systemic support and barriers towards inclusion. Inter. J. Educ. Res. 2019, 93, 232-242. [CrossRef]

28. Hambleton, R.K.; Zenisky, A.L. Translating and adapting tests for cross-cultural assessments. In Cross-Cultural Research Methods in Psychology; Matsumoto, D., Vijver, F.J., Eds.; Cambridge University Press: Cambridge, MA, USA, 2011; pp. 46-74. [CrossRef]

29. Hernández, R.; Fernández, C.; Baptista, P. Metodología de la Investigación, 5th ed.; McGraw Hill: Mexico City, Mexico, 2010.

30. Osterlind, S.J. Constructing Test Items; Kluwer Academic: London, UK, 1989.

31. Lorenzo-Seva, U.; Ferrando, P.J. Factor: A computer program to fit the exploratory factor analysis model. Behav. Res. Meth. Instr. Comp. 2006, 38, 88-91. [CrossRef]

32. Bentler, P.M.; Yuan, K.H. Structural Equation Modeling with Small Samples: Test Statistics. Multivar. Behav. Res. 1999, 34, 181-197. [CrossRef]

33. Blunch, N.J. Introduction to Structural Equation Modeling Using IBM SPSS Statistics and Amos, 2nd ed.; SAGE: Thousand Oaks, CA, USA, 2013.

34. Escobar-Pérez, J.; Cuervo-Martínez, A. Validez de contenido y juicio de expertos: Una aproximación a su utilización. Adv. Med. 2008, 6, 27-36.

35. Schmider, E.; Ziegler, M.; Danay, E.; Beyer, L.; Bühner, M. Is it really robust? Reinvestigating the robustness of ANOVA against violations of the normal distribution assumption. Methodology 2010, 6, 147-215. [CrossRef]

36. George, D.; Mallery, P. SPSS for Windows Step-by-Step: A Simple Guide and Reference (14.0 Update), 7th ed.; Allyn \& Bacon: Boston, MA, USA, 2006. 
37. Timmerman, M.E.; Lorenzo-Seva, U. Dimensionality Assessment of Ordered Polytomous Items with Parallel Analysis. Métodos Psicológicos 2011, 16, 209-220. [CrossRef]

38. Kelley, T.L. Essential Traits of Mental Life, Harvard Studies in Education; Harvard University Press: Cambridge, MA, USA, 1935.

39. Lloret-Segura, S.; Ferreres-Traver, A.; Hérnandez-Baeza, A.; Tomás-Marco, I. El análisis factorial exploratorio de los ítems: Una guía práctica, revisada y actualizada. Anal. Psichol. 2014, 30, 1151-1169. [CrossRef]

40. Carretero-Dios, H.; Pérez, C. Standards for the development and the review of instrumental studies: Considerations about test selection in psychological research. Int. J. Clin. Health Psychol. 2007, 7, 863-882.

41. Clark, L.A.; Watson, D. Constructing validity: Basic issues in objective scale development. In Methodological Issues $\mathcal{E}$ Strategies in Clinical Research, 3rd ed.; Kazdin, A.E., Ed.; APA: Washington, DC, USA, 2003; pp. 207-231.

42. Hair, J.F.; Black, W.C.; Babin, B.J.; Anderson, R.E. Multivariate Data Analysis, 8th ed.; Prentice Hall: Upper Saddle River, NJ, USA, 2018.

43. Fornell, C.; Larcker, D.F. Evaluating structural equations models with unobservable variables and measurement error. J. Mark. Res. 1981, 18, 39-50. [CrossRef]

44. Elosua, P.; Zumbo, B.D. Coeficientes de fiabilidad para escalas de respuesta categórica ordenada. Psicothema 2008, 20, 896-901.

45. Cea, D.; Ancona, M.A. Metodología Cuantitativa: Estrategias y Técnicas de Investigación Social; Síntesis: Madrid, Spain, 2001.

46. Ledesma, R. AlphaCI: Un programa de cálculo de intervalos de confianza para el coeficiente alfa de Cronbach. Psico-USF 2004, 9 , 31-37. [CrossRef]

47. Frías-Navarro, D. Apuntes de Consistencia Interna de las Puntuaciones de un Instrumento de Medida; Universidad de Valencia: Valencia, Spain, 2019. Available online: https: / / www.uv.es / friasnav / AlfaCronbach.pdf (accessed on 17 July 2021).

48. Tavakol, M.; Dennick, R. Making sense of Cronbach's alpha. Inter. J. Med. Educ. 2011, 2, 53-55. [CrossRef]

49. Fox, D.J. El Proceso de Investigación en Educación; Eunsa: Pamplona, Spain, 1987.

50. Dunn, T.J.; Baguley, T.; Brunsden, V. From alpha to omega: A practical solution to the pervasive problem of internal consistency estimation. Br. J. Psychol. 2014, 105, 399-412. [CrossRef]

51. Netemeyer, R.G.; Bearden, W.O.; Sharma, S. Scaling Procedures: Issues and Applications; SAGE: Newcastle, UK, 2003.

52. Valdés Morales, R.; Gómez-Hurtado, I. Competencias y prácticas de liderazgo escolar para la inclusión y la justicia social. Perspect. Educ. 2019, 58, 47-68. [CrossRef]

53. Gómez-Hurtado, I. El Equipo directivo como promotor de buenas prácticas para la justicia social: Hacia un liderazgo inclusivo. Rev. Int. Educ. Just. Soc. 2014, 3, 141-159. 